\title{
ANTUNES, António Lobo. Eu hei-de amar uma pedra. Lisboa: Dom Quixote, 2004.
}

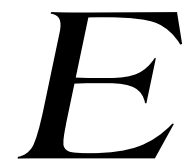

$u$ bei-de amar uma pedra é o romance de um amor confinado. Um homem ama uma mulher que não poderia amar, e é correspondido por ela. O amor é interrompido porque ele acha que ela morreu em um sanatório, uma vez que ela não responde a suas cartas. Ela, entretanto, sobrevive à doença e eles retomam seus encontros de todas as tardes de quarta-feira em uma hospedaria. Os encontros duram 52 anos, até que ele morre de infarto no quarto da pensão. Ele tem mulher e duas filhas, de quem tenta manter escondido seu amor furtivo. Quando ele morre, seu genro, casado com a filha mais velha, é quem vai à pensão transportar o corpo para os funerais.

Eis aí a história principal do romance, contada em mais de seiscentas páginas, divididas em quatro partes: "as fotografias", "as consultas", "as visitas" e "as narrativas".

\author{
Cid Ottoni Bylaardt \\ Universidade Federal de Minas Gerais
}

Na primeira parte, são descritas dez fotografias ligadas à vida do homem e de sua família, bem como de sua amante. Ele criança no colo da mãe; o primo Casimiro, substituto do pai que abandona a família; ele jovem na guerra de Bissau; ele com a mulher cortando o bolo de casamento; com a família na praia, as filhas pequenas, a amante ao fundo; ele promovido na empresa; ele novamente com a família aos cinqüenta anos de casamento num restaurante.

A segunda parte compõe-se de cinco consultas que a amante das quartas-feiras, aos 82 anos de idade, faz com um médico, padecendo tristeza e solidão. Temos aí a história dela com o amante, cujo retrato ela carrega em um medalhão pendurado no pescoço, bem como a do médico, o pai morto de pancreatite, a irmã morta, a mãe insensível, as duas mulheres cadelas. Quem conduz as narrativas é predominantemente $\mathrm{o}$ 
médico, mas há também a voz dela e de outros personagens.

Em seguida vem a seção "as visitas", com três textos. O protagonista, quando criança, visita a madrinha de sua mãe, acompanhado desta; a filha mais nova do homem visita a filha da madrinha da avó; e surpreendentemente a costureira filha da madrinha da mãe do protagonista não recebe mais visita de ninguém, e apresenta-se como a escritora do livro, que no momento faz uma visita à narrativa.

A última seção contém sete narrativas, cujo enfoque predominante é o da morte do personagem masculino na hospedaria após mais de meio século de encontros clandestinos. Curiosa é a quinta narrativa, cuja voz não se identifica, e dirigese em segunda pessoa à filha mais nova do protagonista, dando a entender que está a escrever o livro, que se aproxima do fim, que nesse momento nada mais é do que "um reflexo de coisas mortas".

A narrativa que fecha o livro tem como locutora a amante do protagonista, escolhida pelo escritor para terminar o romance, que ela detesta. Ela é designada para usar a palavra fim, que entretanto não põe fim a nada, não passa de uma palavra, que ela nem liberdade tem de usar quando quer nem como quer, restando-lhe esperar até que alguém expulse todo mundo da narrativa e termine o livro.
Aí está o que se poderia chamar enredo; o que cabe em meia página transforma-se em seiscentas. Como diz Lobo Antunes, qual é o enredo do clássico O velbo e o mar, de Hemingway? E o da Odisséia, de Homero? No primeiro caso, um homem pesca um peixe, os outros peixes comem o produto de sua pesca e ele chega a casa sem peixe; no segundo, temos um homem que inventa mil peripécias para não voltar para casa, onde sua mulher o espera.

No caso de Eu bei-de amaruma pedra, o argumento, com toda sua vulgaridade, é o que menos importa, em que pese a intromissão de uma das personagens, a costureira, que em determinado momento se investe da missão de escrever o livro e procura para ele um final que satisfaça o leitor:

e no entanto uma história alegre tranquilize-se, um romance de amor, gostaria de prometer-lhe que um final feliz e garanto-lhe esforçar-me para um final feliz não apenas por si, por mim, não calcula como preciso (tão cansada) de um final feliz à medida que a claridade declina sem peso no muro acolá, a copa da árvore aumenta, aquilo que resistia no meu corpo (uma porção de cérebro, uma aurícula, alguns músculos) amolece, desiste (p. 429) 
O que importa realmente é o texto de Lobo Antunes, que escreve a banalidade do mundo. É uma escrita atormentada, difícil, cheia de idas e vindas, que não conclui nada, que não ensina nada, que não suscita a expectativa do próximo passo, mas, ainda assim, é bela.

Ninguém se imagina lendo um texto de seiscentas páginas sem um conteúdo muito sedutor. O que prende o leitor nesse imenso relato? A angústia dos personagens, sua vida de perdas e impossibilidades, a incompreensão entre as pessoas, a dificuldade de o ser humano encontrar-se? Antes poder-se-ia dizer que a beleza do texto reside não nas características dos seres humanos que o habitam, talvez porque eles sejam muito semelhantes a nós mesmos e aos que vemos diariamente a nosso redor, mas na angústia da própria escrita, que não consegue conformar-se a um cerimonial literário preexistente. A escrita antuniana, sim, é feita de perdas e impossibilidades, e o acúmulo do insolúvel e do inconcluso gera um incômodo no leitor, que se sente inexplicavelmente arrebatado por esse texto estranho, que fala sem parar e diz muito pouco, para o qual nem a aparente objetividade do significante fim é exeqüivel como significado, que uma outra personagem-escritora, a amante, busca sem cessar, tendo a sensação de estar próxima da tal palavra confusa, mas sem a encontrar, tornando inócua a promessa de final feliz feita pela escritoracostureira.

Mais uma vez, Lobo Antunes nos entrega o vazio em um pacote mais ou menos simétrico. Embora as quatro partes tenham títulos pouco usuais para um romance, como os retratos, as visitas e as consultas, os vinte e cinco textos mantêm uma medida regular, que varia de dezenove a vinte e quatro páginas. É o escritor tentando manter seu controle sobre a narrativa, dividindo-a em partes iguais, mas ao mesmo tempo sendo sugado por ela, como ocorre na "Sexta fotografia", em que ele é convocado pelo personagem Pedrito, que denuncia sua busca de melhorar o romance.

Essa é a escrita que não pende para o sagrado nem busca o humano, não é a palavra equilibrada do homem nem o espelho de sua diversidade, não é a voz ativa nem dos deserdados nem dos sem-voz, não revela segredos, não conduz ao êxtase nem ao desespero. Segundo Maurice Blanchot, o que sempre foi subtraído à linguagem da literatura que se dedica ao homem ou ao sagrado é ela mesma. Quando a obra já não tem mais nada a dizer, aí é que a linguagem aparece, aí é que a literatura se 
volta para sua essência, que não é essencial para o mundo. Esse é o caso de Eu hei-de amar uma pedra.

O que fica para o leitor é uma longa e angustiante espera, o fim que não chega, o termo que não existe, o último esforço para se chegar ao final, que afinal nunca é o último, a dolorosa impossibilidade do fim e da morte. Permanece o ambiente desolador e indefinido do espaço literário, feito de coisas difusas e impalpáveis, como afirma uma voz não-identificada que também participa da escrita:

áspera, indiferente, tranquila, consolar-te pensando que é uma questão de minutos, não muitos, três ou quatro se tanto, um bocadinho apenas, um último esforço e acabou-se, nem a janela se distingue depois, a sala um reflexo de coisas mortas, objectos mortos, de imediato essa claridade vinda não se sabe de onde, da rua talvez, de uma varanda que não se percebe e contudo existe escondida, disfarçada em parede com os seus quadros e os seus móveis numa das paredes que te cercam e no entanto, apesar dos quadros e dos móveis, uma árvore (p. 529) 